\title{
Timebanking in New Zealand as a prefigurative strategy within a wider degrowth movement
}

\author{
Emma McGuirk $^{1}$ \\ University of Otago, New Zealand
}

\begin{abstract}
A movement is gaining traction in New Zealand around timebanks, networks of support in which members exchange favors such as gardening, lifts to the supermarket, pet care, language lessons, career advice, or smartphone tutorials. An online currency is used to track these exchanges, with one hour of work earning one time credit. While each transaction may seem commonplace, when timebanks flourish they work to reshape motivations and opportunities for engaging in labor, and relocalize networks of solidarity, friendship, and resources. Participants reported examples of developing unexpected friendships and renewed enthusiasm for a larger collective project of building alternatives to the currently dominant growth-addicted economic model. These processes contribute to the establishment of foundational, mostly small-scale networks that are enjoyable to use in the here and now, while also creating the potential for these systems to be scaled up or linked together in response to greater economic, ecological, and social changes. Timebank developers in New Zealand are negotiating several structural challenges in their attempts to bring these networks to fruition. This article shares results of ethnographic research amongst seven North Island timebanks, and offers suggestions for future research in this area.
\end{abstract}

Keywords: timebank, community currency, activism, degrowth, New Zealand

\section{Résumé}

Un mouvement est en train de gagner en traction en Nouvelle-Zélande autour de timebanks, des réseaux de soutien dans lequel les membres échangent des faveurs telles que le jardinage, les ascenseurs au supermarché, les soins pour animaux de compagnie, des leçons de langue, des conseils de carrière ou des tutoriels smartphone. Une monnaie en ligne est utilisée pour suivre ces échanges, avec une heure de travail gagner un crédit de temps. Alors que chaque transaction peut sembler banale, quand les banques de temps s'épanouissent, elles travaillent à remodeler les motivations et les opportunités de s'engager dans le travail et relocaliser les réseaux de solidarité, d'amitié et de ressources. Les participants ont signalé des exemples d'amitié inattendue et d'enthousiasme renouvelé pour un projet collectif plus vaste consistant à construire des solutions de rechange au modèle économique actuellement dominé par la croissance. Ces processus contribuent à la mise en place de réseaux fondamentaux, pour la plupart à petite échelle, qui sont agréables à utiliser ici et maintenant, tout en créant le potentiel pour que ces systèmes puissent être étendus ou liés ensemble en réponse à de plus grands problèmes économiques, écologiques et sociaux changements. Les développeurs de timebank au sein de la Nouvelle-Zélande sont en train de négocier plusieurs défis structurels dans leurs tentatives de faire fructifier ces réseaux. Cet article partage les résultats de la recherche ethnographique parmi sept banques de temps de l'île du Nord, et propose des suggestions pour les recherches futures dans ce domaine.

Mots-clés: banque de temps, monnaie communautaire, activisme, décroissance, Nouvelle-Zélande

\footnotetext{
${ }^{1}$ Emma McGuirk, PhD Candidate, Department of Anthropology and Archaeology, University of Otago, PO Box 56, Dunedin 9054, New Zealand. Email: emma.mcguirk "at" gmail.com. I would like to thank Susan Paulson and the anonymous reviewers for their encouraging and thought-provoking feedback. I am also grateful to Lisa Gezon and Susan Paulson for convening the degrowth panels at the 2015 Annual Meeting of the AAA, and for organizing this collection of articles for the JPE. I also thank the University of Otago, and the Department of Anthropology and Archaeology, for financial support for this research, and the Association of Social Anthropologists Aotearoa New Zealand (ASAANZ) for assistance to attend the AAA meeting in Denver. Above all, I thank the participants of this research for sharing their experiences and reflections so generously. This is the tenth article in Lisa L. Gezon and Susan Paulson (eds.) 2017. "Degrowth, culture and power", Special Section of the Journal of Political Ecology, 24: 425-666.
} 


\section{Resumen}

Un movimiento está ganando fuerza en Nueva Zelanda alrededor de los bancos de tiempo, redes de apoyo en las que los miembros intercambian favores como jardinería, ascensores al supermercado, cuidado de mascotas, clases de idiomas, asesoramiento profesional o tutorías de teléfonos inteligentes. Una moneda en línea se utiliza para realizar un seguimiento de estos intercambios, con una hora de trabajo ganando un crédito de tiempo. Mientras que cada transacción puede parecer un lugar común, cuando florecen los bancos de tiempo trabajan para remodelar las motivaciones y las oportunidades para dedicarse al trabajo, y relocalizar redes de solidaridad, amistad y recursos. Los participantes informaron de ejemplos de desarrollo de amistades inesperadas y renovado entusiasmo por un proyecto colectivo más amplio de alternativas de construcción para el actual modelo dominante de crecimiento económico adicto. Estos procesos contribuyen al establecimiento de redes fundacionales, en su mayoría a pequeña escala, que son agradables de usar en el presente y ahora, al mismo tiempo que crean el potencial para que estos sistemas se amplíen o se unan en respuesta a mayores problemas económicos, ecológicos y sociales cambios. Los desarrolladores de timebank dentro de Nueva Zelanda están negociando varios desafíos estructurales en sus intentos por llevar estas redes a buen término. Este artículo comparte los resultados de la investigación etnográfica entre siete bancos de tiempo de la Isla Norte, y ofrece sugerencias para futuras investigaciones en esta área.

Palabras clave: banco de tiempo, moneda de la comunidad, activismo, decrecimiento, Nueva Zelanda

\section{Introduction}

The maxim "We have what we need, if we use what we have" attributed to the founder of the contemporary timebanking movement, Edgar Cahn (2004: xv), is a popular phrase repeated in the websites and brochures of timebanks across New Zealand. It sums up neatly a key component of timebanking philosophy, by calling on members of post-industrial societies to become more creative in using and distributing the abundance of manufactured resources already produced, and the existing skills and talents of community members. This maxim allows for a relative reduction in focus on producing more and more consumer goods, and striving to earn enough money to pay for them. Demaria et al. (2013) identify this perspective as one of the sources of conversations within degrowth literature and activism, about the longterm purpose of our lives and how to achieve well-being. A move to support degrowth acknowledges people's need for stability and a secure livelihood, while developing a vision for simple lives that are "liberating and profound rather than restraining or limiting" (Demaria et al. 2013: 197).

Transitioning to post-carbon energy and transport systems has also been examined as complementary pathways towards degrowth, downsizing and voluntary simplicity. The aims and philosophy of timebanking align with these, and with advancing human happiness and flourishing through strong and diverse sets of social relationships that derive strength and longevity from a healthy biosphere and community, rather than through material and technological development alone. Timebanking coexists in complementarity and in tension with other experiments to build alternative economic spaces. Timebanks have been established through iterative cycles of development in many New Zealand locales, amongst communities that have also tested, evaluated, and modified other forms of community currencies. These processes have led to the creation of foundational, mostly small scale networks that are enjoyable to use and experiment with in the here and now, but that also contribute to wider strategies of laying foundations for broader systems. Timebank developers interviewed for this project emphasized these dual priorities: tangible rewards of the current application, and potential for these systems to be scaled up or linked together in response to - and as part of - greater economic, ecological, and social change. Relations between these priorities are explored throughout this special section in response to questions raised in the introduction (Paulson 2017) about dynamics of culture and power that constrain or enhance the transformative potential of modest practices and relationships. By paying close attention to practices and relationships within the context of timebanking, this article contributes to discussions about how to catalyze the necessary changes that could allow equitable downscaling of production and consumption, in order to increase human well-being and enhance ecological conditions. 
Literature characterizes timebanking as largely egalitarian in its aspirations, emphasizing the equal value of all forms of labor, and the equal opportunity for all members of society to participate. My research has followed activists throughout New Zealand over the past few years as they have variously attempted to bring these egalitarian dreams to fruition. I have watched them negotiate the following tensions: building timebanks alongside and within existing community support networks; engaging in a prefigurative movement while remaining embedded in a late capitalist economy; and the pressure to invest large amounts of unpaid hours into establishing the administrative support behind timebanks. In the spirit of supporting these innovative and challenging projects, this article responds to Burke and Shear's (2014:135) work in articulating political ecologies of hope and possibility:

Gibson-Graham contend that much of social theory, by virtue of its capitalocentrism, has had the perverse effect of creating a path from the present to a capitalist future. Our hope for a non-capitalist, non-capitalocentric political ecology, is to engage in and help perform a multiplicity of other paths that lead to other futures.

Timebanks help to create blended transition spaces that allow members to experiment with new forms of non-capitalist exchange, while continuing to participate in the market and waged labor. By advertising and recording timebank trades online, new pathways towards these non-capitalist forms of exchange are made more explicit, and therefore easier for neighbors and new acquaintances to follow.

In the process of maintaining these transitional spaces, timebank developers encounter and negotiate several key tensions, as listed above. Building timebanks in connection with existing community networks can entail significant negotiation work to establish when and where timebanking is most useful. Timebanks can catalyze new relationships and exchanges if there is mutual need and interest, and this is not always the case within well-established friend and family support networks. In addition, timebank members' relationships change over time, in some cases leading to friendships in which it is no longer deemed necessary to record ongoing favors in the online system. In addition, organizers often personally embody the transition spaces (between capitalist and non-capitalist economies) that timebanks create, maintaining livelihoods that are at times a precarious combination of paid and unpaid work. Developing prefigurative practices (new styles of relationship that seek to prefigure or lay the groundwork for more equitable futures) is time-consuming work. It is easier to maintain a long-term contribution with some form of reliable financial support, or freehold land. Although it can be challenging to maintain thriving alternative economies under these conditions, many participants interviewed for this research demonstrated a high level of commitment to timebanking and related strategies for economic and social reform.

This article explores participants' commitment to developing timebanks from several angles, including their personal goals and interests, and structural constraints that can contribute to a loss of commitment and motivation. Timebanks in New Zealand have emerged from within a broader context of degrowth related initiatives and activist projects, although the term degrowth itself was not used when I conducted fieldwork. As one example, efforts to develop and maintain alternative currencies have been underway for several decades within New Zealand, and this article links that history to contemporary projects and challenges. With regard to the continued longevity of timebanks, although many participants were actively engaged with local and national government to discuss and promote local currencies, they often expressed doubt that direct lobbying or partnership with government was the most effective, efficient, or strategic path to achieving the changes they hoped to realize within their communities. As tools for evaluating timebanks' success, both qualitative and quantitative data is presented, and important considerations for evaluating this data are discussed. The closing sections of this article consider the wider educational benefits of timebanking, and areas for future research.

\section{Methods}

I first learned about time banking at a permaculture conference in New Zealand in 2010. When I began $\mathrm{PhD}$ research on timebanking in 2011, I decided to utilize an activist ethnographic approach, 
incorporating elements of participatory action research (PAR), following the interests of the communities I was working with. I have since undertaken twenty recorded interviews, with attendant observations, field notes, and informal interviews. I have also contributed to national organizing and collaboration, and I have been observant in my own participation as co-founder of the Dunedin Timebank, which is located in the South Island. All of the recorded interviews were conducted in the North Island, with the organizers and members of seven timebanks. Almost all participants in recorded interviews chose not to remain anonymous; as a result some participant's names are included with direct quotes later in this article. At times I found it difficult to maintain a balance between the activist and academic goals of my research (it was sometimes impossible to make a distinction between the two) however, it is clear that this approach has yielded great opportunities for participant observation, rich conversations during recorded interviews, and many opportunities to share knowledge gained from research directly with the participants of this study.

As Burke and Shear (2014) assert, at this time of mounting ecological, social, and economic crises, constructing intellectual critique alone is no longer an adequate contribution. Rather, they call for engaged scholars of political ecology and related disciplines to contribute to activist and social movements through the following approaches: 1) examining, describing, and publicizing the numerous experiments in alternative economies that are already in progress, 2) helping to further develop the visions and narratives that guide these experiments, and 3) actively co-constructing and supporting these alternative economies and ecologies (Burke and Shear 2014:130). Throughout my ethnographic research I have endeavored to enact all of the above, at different times, incorporating additional aspects of PAR as and when possible. While doing so, I have also continued to read and draw on the long established history within anthropology of designing activist, applied, engaged, collaborative, and dialogic methods that are tailored to local contexts, and to participants' interests and capacity to collaborate. I have described this process in further detail, and what the New Zealand literature in particular contributes to PAR methods, in a previous article (McGuirk 2012).

\section{Participants' motivations for developing timebanks}

Participants in my research reported a range of motivations for developing and participating in timebanks. These included desires for community-building, to meet new people, and to take part in something innovative. Some of these desires drew on romanticized notions of 'close-knit communities' from the past; however participants in my research did not find the experience insular. Most of the participants I encountered during this study described their primary goal as building larger networks of solidarity, neighborliness, friendship and support, with the timebank infrastructure and currency viewed as a means of achieving these outcomes. Some participants also expressed deep misgivings about the stability and longevity of the current market economy and global financial systems. Participant concerns about the unwanted contraction or decline of reliable paid employment connected with perceptions of a lack of autonomy within an economic system where privately owned banks (most of which are foreign owned, from the perspective of New Zealand residents) play such a large role in determining New Zealand's economic and monetary policy. A further motivation was a desire to redirect human labor and energy out of the market economy, although this was balanced with an awareness of the limitations of timebanks' ability to achieve this, especially in the early stages.

As Kallis and March (2015: 362) explain, degrowth is an expansion and continuation of practices that have long been underway, "... degrowth reads the capitalist present as full of latent elements from a noncapitalist past, such as the gift economies of barter markets or the commons of urban gardens; it is these that carry the seeds for a different future." Many of the participants interviewed for this research had followed the rise and fall of LETS, Green Dollars, and timebanks in other countries, and were conscious of the need to learn from these examples, while adapting their projects to suit New Zealand contexts. Although concern with promoting structural change often featured in the backdrop of our conversations, the most common motivations reported for developing timebanks were to build stronger local relationships and to expand nearby social networks. Many participants viewed timebanking as an opportunity to build on and extend activities that they were already involved in, such as church support groups, coaching children's sports 
teams, exchanging favors with friends and family, volunteering for a diverse set of community organizations, and using peer to peer exchanges such as AskShareGive, ${ }^{2}$ Couchsurfing, ${ }^{3}$ Freecycle, ${ }^{4}$ and WWOOFing. ${ }^{5}$

\section{Timebanking and degrowth in New Zealand}

Beginning in New Zealand in 2004, timebanks have the developed in more than 25 locations, both urban and rural, drawing inspiration from models in Europe and the United States. Timebanks are small-scale alternative currency systems in which members use one hour of work as the unit of currency. Members maintain an online account balance, which tracks their earning and spending. Forms of labor commonly exchanged in New Zealand in these networks include: music and language lessons, rides to the airport, babysitting, cooking (lessons, and delivering meals), working bees on members' gardens, CV editing, skype and smart phone tutorials, life coaching, home maintenance, and projects completed in partnership with schools and community groups.

While I have not heard the term 'degrowth' used in New Zealand in connection with timebanking, I perceive that the timebanks I studied, together with the aligned organizations and social movements that operate behind and alongside them, share in the broad visions and philosophy advanced by other actors and movements who/that are using the term. Together the diverse range of projects and protests associated with degrowth encompass acts of creating alternative pathways and lifestyles, as well as direct political challenges to the status quo of unchecked economic growth and development. These include environmental advocacy and activist organizations, which have a long history in New Zealand, and now include new groups focused on reducing the impacts of climate change, such as Generation Zero, a youth led organization working towards a "safe, thriving, zero carbon Aotearoa" (Generation Zero Inc. 2011). The Transition Towns movement, which advocates for a careful, managed transition to a post-fossil fuel economy, is also underway in New Zealand, although it has not become as widespread as in the United Kingdom. Many of New Zealand's current timebanks emerged directly from Transition Towns groups. As timebanking was established from the grassroots level throughout New Zealand, many of the volunteer developers who created New Zealand's timebanks had previously been involved in the organizations described above, and many continue to work on additional projects for social justice and environmental restoration alongside developing their local timebank. I have attended public screenings of documentaries in New Zealand including the 2011 film Growthbusters (Gardner 2011) that were hosted by timebanks. These film screening and discussion evenings have examined a range of environmental and social problems, including the need to transition to a post-growth society.

\section{Coordinators' role}

One of the initial points of interest for my research was the tendency within promotional literature to describe timebanks as largely self-managing, simple to understand and explain, and likely to be taken up with enthusiasm by the members of a given community once the online software is provided. My research revealed more varied experiences of timebank developers and members. A key aspect of timebanking that is under-acknowledged and under-researched is the extensive unpaid work of founding members and coordinators to get timebanks up and running, and to maintain them. In New Zealand most timebank coordinators are women, they are sometimes paid, but mostly in voluntary positions. In addition to helping facilitate trading as and when needed, the coordinators also carry out: social event organizing; networking with aligned community organizations; fundraising and grant writing; administration; marketing and media

\footnotetext{
${ }^{2}$ AskShareGive was developed in New Zealand in 2012. It is an online platform that allows people to exchange favors and support in a similar style to timebanking (without creating a new currency however), as well as exchanging unwanted household goods (www.asksharegive.org.nz).

3 Couchsurfing is a global network of hosts and travelers offering free accommodation in their homes (www.couchsurfing.com).

${ }^{4}$ Freecycle is an online network for the donation and redistribution of unwanted household items (www.freecycle.org).

${ }^{5}$ WWOOFing, which stands for Willing Workers on Organic Farms, or World Wide Opportunities on Organic Farms, is a loose global network of organizations that connects travelers with hosts living on organic properties, for the opportunity to to do farm work in exchange for room and board (www.wwoof.co.nz).
} 
outreach; training and induction of new members; ongoing technical and IT support for existing members; and national and international collaboration with other timebanks. It is a busy role and one that paid coordinators often struggle to keep contained within their paid hours - usually between 10 and 20 hours per week.

Strategic planning, succession planning, and capacity building are also key tasks and processes undertaken by coordinators, sometimes with the support of an active voluntary committee or steering group of timebank members. As one paid coordinator explained to me during an interview, she was excited to hear the goal discussed amongst founders of her timebank to increase membership from 200 to 400 members, however, with 200 members to keep in regular contact with, she was already finding it challenging to prioritize and maintain her workload at 20 paid hours per week. She found it hard to resist the temptation to put in additional unpaid hours, when there was always so much to do. Therefore, she explained, achieving and maintaining the goal of 400 active trading members would require a matching increase in staffing. This could take several forms, either finding extra funding to pay her for 40 hours per week, hiring a second parttime coordinator, or building up the capacity for regular sustained voluntary contribution towards the administration of the timebank. This has sometimes proved to be challenging for timebanks to achieve as they grow. In some cases the growth in membership has come at the expense of the wellbeing of coordinators and organizers, who have become burnt out and abruptly left their roles as coordinators, either permanently, or for a period of time until they are rested and able to return to work. In these instances a key tension emerges between the egalitarian values within the wider timebank philosophy (one hour's work for one time credit, redefining work so that all forms are valued equally, everyone's contribution is respected and so on) and the frequent pressures faced by coordinators and committee members to work in a role of great responsibility and expectation, sometimes beyond their capacity or desire to do so.

\section{Earlier alternative currency networks in New Zealand}

In the 1980s and 1990s prior to the establishment of timebanks, New Zealand had up to 60 different Local Exchange Trading Systems (LETS), usually referred to as Green Dollars. These networks were studied and documented by Jackson (1995) and Williams (1996) shortly after their peak, and later on by North (2007). Almost all of these systems had declined by the turn of the century, with only a few left in operation today - mostly in isolated communities, notably HANDS in Golden Bay. In some locations, developers who have previous or concurrent experience of administering a LETS or Green Dollars network are now running timebanks. Two participants that I interviewed also brought knowledge from overseas: one had been a member of a LETS in Australia, and another had visited timebanks in the United Kingdom prior to helping establish one in New Zealand. Participants interviewed for this research demonstrated an interest in experimenting to find forms of alternative currencies that seemed to work best, and that their fellow community members showed the most interest in. They were developing these systems alongside each other in some locations, to play to their different strengths.

Alternative currencies often attract greater numbers of participants when the market economy is weak, and unemployment is high. North (2007: 127-128) explains the rise in New Zealand's Green Dollars network from the mid-1980s onwards as a response to the volatility in economic conditions. This period was characterized by implementation of policies designed to deregulate financial markets, put an end to the compulsory arbitration of wages and salaries, privatize state assets, and reduce social welfare spending. During this period, growing disenchantment with the promises made by neoliberal policy contributed to the uptake of Green Dollars as one method for strengthening community economies. When New Zealand's economy recovered in the 2000s, participation in Green Dollars networks declined as members returned to longer hours of paid employment. Participants had to balance competing desires and obligations towards community building, engaging in alternative spaces, putting food on the table, and paying the rent. Even though participation was flourishing in some networks, opportunities for full time paid employment were taken up if and when they became available again, thus reducing members' available time and energy to participate in Green Dollars exchanges (North 2007). This shift was not only due to the attraction of more 
paid work, but also obligations to pay tax on Green Dollars income, and the fear of having welfare payments docked or suspended as a result of earning even modest amounts in Green Dollars (North 2007: 143-144).

\section{The Inland Revenue Department and timebanking in New Zealand}

A range of government policies in New Zealand work to incentivize full-time employment within the market, and to simultaneously restrict or sanction attempts to create alternative livelihoods. Contemporary policies include a complicated system of economic sanctions imposed by Work and Income New Zealand (WINZ) on unemployed beneficiaries when they earn part-time income. Unlike the situation in the United States and the United Kingdom, where time credits are not taxable, and the established tax on earnings in LETS in New Zealand, the position of New Zealand's Inland Revenue Department (IRD) with regard to the tax status of 'income' earned in the form of time credits has not yet been formally articulated. Written correspondence has taken place between several timebank founders and staff at the IRD, who have advised caution with regard to members earning time credits for their professional skills. Advice from senior staff at the IRD has been that members of timebanks in New Zealand should not earn time credits for the same kind of work that they also earn their primary wages for. In other words, builders should not earn time credits for building or home renovation work; teachers should not earn time credits for teaching, and so on. The resulting limitations are clear with regard to the range of skills and depth of experience on offer within timebanks as a result of these restrictions. Although there has been no official ruling, timebank coordinators I spoke with were hesitant about entering into further dialog with the IRD, and so they elected to instruct their members (usually at the time of signing up to the timebank) to err on the side of caution, and refrain from offering their main professional skills within the timebank. On the other hand however, several timebank members explained that they did not perceive this as a limitation, as they spent more than enough time during the week engaging in their main form of waged labor, and in their leisure time they preferred to develop new skills and hobbies.

Timebank members also found ways around this limitation. In one North Island timebank I met a former hairdresser (now full-time mother), who happily provided haircuts in exchange for time credits, and was not concerned about any potential conflict with the advice from staff at the IRD, as she no longer earned any cash income from this skill. Another timebank I spent time at had a retired plumber offering his services, and in a further example, a currently employed physiotherapist explained to me that while she did not offer any hands on physiotherapy treatments (also because this would contravene health and safety, and insurance regulations), she did meet with timebank members to discuss their physiotherapy needs, concerns, and treatment plans. She often gave advice while out walking with them. This is the sort of advice and support one might hope to receive from a friend, if fortunate enough to have a friend who is also a physiotherapist. One of the most frequently praised features of timebanks, amongst interview participants, was being able to access a wider range of people's skills than would otherwise be available through friendship and kin networks, or through the market economy. Despite the clear cost savings for governments of having more people engaged in this sort of preventative health care, and being connected to wider and more resilient social networks, timebanks have had little success in garnering direct government support in the form of funding for part-time coordinators' salaries, or the removal of bureaucratic obstacles such as the concern around taxation.

\section{Small scale solutions in dialog with government reform}

In addition to setting policy regarding tax obligations or exemptions for local currencies, governments manage political economic systems in which income (and income tax) is generated within communities that are supported by substantial amounts of unpaid labor. However, direct support from national or local government for policies or programs (including timebanks) that support the unpaid work carried out in homes and community settings has been mixed across New Zealand. This is consistent with a wider contemporary climate in New Zealand of cuts to social welfare, and cuts to funding for social services and community groups across the board. Research participants also reported mixed results from conversations with their local 
Ministers of Parliament (elected national representatives) about the possibility for greater government support of timebanks, either through funding or other means.

Some participants viewed their involvement in timebanking as a welcome break from more confrontational or contentious forms of activism. Timebanking is generally presented as a politically neutral activity to prospective members, with a strong emphasis on the inclusive nature of timebanks - that they are open to everyone, from any religious, political, or other affiliation, that timebanks welcome people from all walks of life. As North (2010: 79) points out, this approach carries within it a risk of downplaying the full implications of the transition that local currency developers are advocating for:

... as local money circulates in a small geographical area, it is a tool for localizing economies, reducing transport costs, and, if fully adopted, it would lead to a diversity of small economies rather than large economic monocultures [...] It is thus deeply political, even if those who promote it often deny that what they are arguing for is in any way controversial.

Interviewees did not describe the focus on community building through timebanking as avoiding controversy, rather as part of a range of projects and tactics that people were using to support a transition to post-growth economies. Often drawing on models found in nature, in which diversity ensures resilience, participants emphasized the need for a variety of inter-connected political and economic systems, particularly at the local scale. In addition, many participants interviewed for this research were veterans of public protests, lobbying, petition organizing, submissions to parliament, acting as board members of community groups, being consulted with by government taskforces, and even working as elected members of local government themselves. Participants reported some success in engaging with government in this way, however, many also reported frustration, burn out, and disenchantment. This was especially the case with protests and submissions that had reached a successful outcome, with the desired policy or law change enacted as a result, only for it to be reversed following the next election. Therefore, timebanking and other prefigurative approaches to improving society at the local scale were seen as a crucial component to have alongside more direct engagement with government (to achieve monetary reform) that Dittmer (2013) and others advocate for.

\section{Sudden and chaotic changes to local needs, and timebanks' response}

A time of sudden and urgent need for the alternative networks of labor and support that timebanks provide has already occurred once in New Zealand. Following the Canterbury earthquakes of 2010 and 2011, the Lyttelton Timebank saw a rapid influx of new members, and increased trading activity (Ozanne and Ozanne 2016). This process shares some similarities with the rapid growth of barter networks in Argentina following the economic crash in 1998 to 2002, as described by Dittmer (2012) and North (2007). In Lyttelton, the successful response of the timebank following the earthquakes was made possible by the community building work undertaken from 2004 to 2010, which established the administration and practice of timebanking when things were more settled before the earthquakes occurred. By 2010 the Lyttelton Timebank's 330 individual members and nineteen organizational members had collectively exchanged more than 30,000 hours' worth of work and support (Ozanne and Ozanne 2016: 9), developing along the way new sets of interpersonal connections and relationships, as well as new working partnerships between the timebank and other community organizations.

In the aftermath of the earthquakes, timebank members provided practical support to each other by removing damaged brick chimneys from houses (freeing up emergency services personnel for more challenging tasks), and also providing much needed companionship and support. In partnership with the local medical centre, timebank members phoned and visited all elderly residents in the community, to check that they were safe and to find out what help they required, as well as to converse and provide information. These are just two out of numerous examples of important work done by timebank members following the earthquakes. The timebank had already established a detailed database of members' skills and resources prior to the earthquakes, and this information, combined with a highly efficient, personalized system of 
communication, enabled the timebank to deliver an agile and flexible response to the crisis (Ozanne and Ozanne 2016).

The Lyttelton Timebank is New Zealand's first timebank, and it now has more than 730 members, representing a high percentage of the town's 3,000 inhabitants. It is likely that all residents of Lyttelton are now connected to the timebank in some way, either as members themselves, or through a friend, family member, or coworker who is in the timebank. In addition, the timebank supports a number of community projects, events, and large annual festivals in Lyttelton by providing volunteers (who earn time credits) to help organize and deliver these events.

\section{Considerations for counting time credits and recorded time trades}

Outputs and results of timebanking can be measured both quantitatively and qualitatively. My qualitative research exploring people's experiences within timebanking has been complemented by quantitative attention to the growth (and disappearance in some cases) of recorded exchanges within several timebanks. One of the quantitative tools for measuring the success of a timebank is the frequency and overall number of exchanges recorded in the online ledger, as mentioned above in the Lyttelton Timebank example.

Almost all of the timebanks in New Zealand use Community Weaver - online timebanking software developed and hosted in the United States. Community Weaver collects a record of all exchanges made within a timebank, including the number of hours recorded for each time trade, and the cumulative number of hours across the timebank as a whole. This is an extremely useful record for the coordinators and members of a timebank to refer to. However, there are also important considerations to take into account with regard to using this online record as a measure of the success or growth of a timebank.

Many timebank trades are never recorded in the online system. Through participant observation, recorded interviews, and informal interviews, I came across numerous examples of timebank members not recording their exchanges with one another. This could occur for a variety of reasons, including that after meeting through the timebank, the relationship between two people shifted from acquaintanceship to friendship, and as a result it no longer felt necessary to either person to record the timebank trade and 'make it official'. Timebank coordinators that I spoke with about this practice were mostly happy to hear from their members that this was occurring, viewing it as a sign of successful relationship building. However, they also held reservations about the impact this was having on the record of steady progress within their timebanks. Their reservations were not only centered around needing the statistics to present a positive record to external observers (such as funders, the media, and prospective members), but also that seeing the timebank trades recorded regularly was a source of motivation for themselves, and the other members. Seeing the record of exchanges steadily ticking along was not only a source of motivation to keep going, but also a source of inspiration when reading about novel and creative ways that people were using the timebank, as the record often contained a brief note to explain each exchange. A further necessary consideration is that diverse and immeasurable outcomes often occur. Many timebank trades do not fit neatly into a format of one person giving help, and one person receiving help. Shared experiences such as gardening and working bees, or meeting up to exercise together, can be difficult to record in Community Weaver when all participants of the time trade feel they have gained something from the activity.

The wider membership cannot access the full online trading record so an important job carried out by coordinators was to regularly broadcast new and interesting trades via blog posts and email newsletters. These blog posts and email newsletters promote and normalize community focused or alternative economic practices (within partner organizations as well as the timebank), and build community ties by profiling individual members of the timebank and their unique contributions. This makes it more likely that people will recognize each other at social events and know a little more about each other's backgrounds and interests. In the Wellington Timebank a journalism student (and timebank member) earned time credits for interviewing timebank members about time trades they had enjoyed, and she wrote these stories into captivating short articles that were emailed out one at a time with accompanying photographs, as part of a series of Wellington Timebank newsletters. Several New Zealand timebanks, including the Wellington 
Timebank, have a subscribers list for these email announcements and newsletters that extends well beyond the timebank membership alone.

\section{Further educational benefits of timebanking}

Experimenting with small-scale alternative currencies can have other flow-on benefits for participants, in addition to those described above. Becoming involved with a timebank or Green Dollars network gives people opportunities to have conversations that they had not been exposed to before. This is one of the most important roles that alternative currencies can play - as tools for public education about the social and cultural production of money. The question "Where does money come from?" is not adequately discussed in New Zealand's public schools and media, and people are often surprised to learn of the extensive (and profitable) role that private banks play in creating the money supply. Several timebanks in New Zealand are now developing a higher profile in local and national media, so even with membership numbers remaining relatively small, a much larger percentage of the New Zealand population has heard about these networks, and listened to interviews and conversations about why and how a group of people might want to get together to create their own currency. As Deirdre Kent explained during our interview:

I think that timebanks are the perfect way to educate the committee members and the organizational people about the money system, that, look, "We're a community and we're creating our own credit, and it doesn't have any interest, isn't that wonderful, it works!" I mean, that to me is the grassroots way of teaching people about the money system. That it is our commons, and we have a right to claim it and use it, but we don't have any right to charge interest. (Deirdre Kent, Otaki, 2012)

As these conversations evolve amongst timebank organizers, many start to participate in detailed discussions about what debt is and how it emerges within the market economy, comparing this to their lived experiences of both creating credit and accruing a form of debt, or 'negative credits', within their timebank accounts. A further point of conversation amongst timebank developers is how best to interweave the new timebank relationships, and new social obligations that are forming, into pre-existing social circles of informal favors, bartering and skill swaps. This is an on-going process of discovery and negotiation as timebanks expand.

\section{Living within competing economic paradigms}

As mentioned above, many of the participants interviewed for this research project were engaged in other activist projects, and were well-read regarding current and looming crises such as climate change, peak oil, high extinction rates, loss of high quality topsoil, global fresh water decline, and other serious environmental challenges at the local and global scales. In addition, they were concerned about the longevity of global economic and financial systems that depend upon the continued extraction of finite natural resources. At times, this information weighed heavily on the minds of the people that I interviewed. Participants often sought out like-minded individuals and groups in order to share their concerns, and to find actions and activism to get involved in as an antidote to overwhelm and apathy. This anxiety about a future in which fundamental aspects of the formal economy may become radically different during their lifetimes also produces a complicated set of priorities in the here and now. Participants engaged in building different kinds of social, economic, and cultural capital, within two broad categories. On the one hand, accumulating the experience, skills, and networks needed for the cash economy, to help towards finding a steady job, and paying the bills. On the other hand, building up social contacts with people living in intentional communities throughout New Zealand, studying local food production and energy efficiency, downsizing, lobbying local government to clean up polluted rivers near their homes, and doing whatever else seems necessary to prepare for alternative future livelihoods, that can hopefully be adapted to suit a world that may become severely ecologically compromised. This can be a complicated path to tread, as engagement with the cash economy and waged labor can push and pull one's life path in directions that are unintended. These outcomes do not 
necessarily unfold with linear progression towards independence from the market, or the creation of viable alternative spaces, within hoped for timeframes. Participants of this research were living with one foot in the world of conventional economic growth, and one foot in a world of post growth, or purposive degrowth. They were using their activism to plant seeds now in the hope that they will bear useful fruit not only today, but also in years to come. As one participant explained, when we discussed the negative changes that could be around the corner:

I try not to think about it too much because I end up either getting scared, or thinking "Why isn't it happening already?" but you know, if you are interested in things, as I guess we are, you get the feeling that we're on the cusp of some pretty major change. But then, you know, it's quite easy to slouch out, business as normal, watch telly and whatever else. I don't know, I find the time that we live in, maybe everyone's always found this, but I find it quite difficult to deal with. (Marcus Baker, Whakatane, 2012)

A key benefit that I observed for activists who were engaged in timebanking, was that it facilitated more frequent opportunities to live according to their values, to do something positive and helpful that provided benefits right across the different sets of priorities that they are trying to negotiate. This appears to be part of the reason that people kept returning to work long unpaid hours for the development and administration of their local timebanks, even to the point of burnout. The risk of burnout was sometimes considered worth it, for the pleasure and satisfaction that arose when participants were afforded opportunities to resolve some of the tension around negotiating and living within different economic paradigms, in both their present situation, and their imagined potential future(s). Participants often also spoke at length about the socially produced aspects of economic and political systems, and the roles that they play in reproducing them. As Burke and Shear (2014: 129) also explain, with regard to both past and contemporary environmental and social crises that are unfolding:

These crises are not unhappy accidents of an economy that is simply out of balance, nor do they result from inadequate or excessive regulation or the unjust actions of a few bad apples who let greed get the best of them. Rather, they result from the social relations that define our lives, relations that produce and are produced by particular ways of understanding, knowing and being in relation to an economy and ecology that we have come to see as natural and inevitable.

Timebanking is one part of participants' efforts to produce and create society differently, through different ways of inter-relating with the people and commodities around them. Maintaining alternative economic spaces that are interwoven with capitalist systems is challenged by the fact that members of a timebank or Green Dollars network cannot step out entirely of the social relations and the performative identities that are tied into capitalist economies and political ecologies that can appear fixed, external and inevitable. As a contrasting example, one of the goals of the Back to the Land movement (in which rural intentional communities were established) was to achieve increased separation and independence from the web of relations that constitute and co-create the market and the state. The members of timebanks on the other hand, continue to reside in cities and towns. This means maintaining a greater degree of engagement with waged labor, individually managing mortgage and rent payments, and consumption practices, while at the same time reaching out to build new networks of solidarity, trust and reciprocity. Timebank members are seeding and nurturing the growth of alternative economic spaces during their time off from work, in the evenings and weekends. As a further complication, the majority of participants interviewed for this research, and the wider group of timebank members I met in different locations, generally had stable lives with regard to housing and income (whether full or part-time paid work). It therefore remains a challenge within the timebanking movement in New Zealand to find ways to support people in more precarious situations. The problems that make it less likely for people on low incomes to participate in alternative currencies, as 
outlined by North (2010: 83-85) are also relevant in contemporary low-income communities in New Zealand. As North identifies, these challenges can include: benefit worries, uncertainty, insecurity, isolation, low levels of confidence and energy, and unsettled circumstances - which is especially true with current benefit levels in New Zealand being set below survival rates in relation to the cost of living.

\section{Future research}

Looking back over the past few years of my research and fieldwork, and comparing the situation of New Zealand timebanks in 2011 to the present day, I see that many timebanks have increased in size, public profile, and trading activity. However, another group of timebanks have suffered from falling membership rates and a decline or complete halt in trading activity. As Table 1 demonstrates (see below), almost half of New Zealand's established timebanks had no trading activity recorded for periods of twenty weeks or longer. The timebanks listed in Table 1 are arranged with the timebank that had the most recent exchange first (Timebank 1), through to the timebank with the longest break between the last recorded exchange and the present day (Timebank 26). In several cases, no trading had occurred for more than one year, and these timebanks have mostly likely folded. I have anonymized the data in this table as I do not wish to give the impression that any particular timebank has folded when this may or may not be the case. Further interviews would be required to establish this. During the course of my fieldwork, I have twice observed timebanks experiencing a hiatus in trading activity due to the loss of coordinators or key activists, only to see them return to active participation at greater levels later on, when the organization and administration behind the timebanks were better established. Future research could explore the background information and context of timebanks that have recently folded or are experiencing a significant decline in trading.

The Dunedin Timebank experienced a combination of events in 2014 and 2015 that led to the timebank being placed into what committee members called 'cryogenic suspension.' Our umbrella organization restructured and returned to focusing on its core operations and core mission, which meant that it reduced support for the Dunedin Timebank and other community groups. The organization also decided not to renew its lease on the central city office building it had been based at, so the Dunedin Timebank lost its office space and headquarters. At around this time only part of the funding for the coordinator's position was renewed. What remained was not enough to continue her part-time salary for the next 12 months, so we transitioned back to being volunteer-run sooner than planned. The sum of all these and other challenges brought trading activity and social events to a halt. Conversations are ongoing amongst the committee and wider membership however, with regard to restarting the timebank with a different administrative structure.

Not all of New Zealand's timebanks have access to funding to employ a part-time paid coordinator, and those that do are conscious of the need to also develop organizational systems that could withstand loss of funding (either temporary or ongoing), and strategies to transition to full voluntary management if needed. One strategy employed successfully by the Wellington Timebank has been to develop regional hubs across the city. At these local hubs (collections of neighboring suburbs), experienced timebankers have hosted informal get-togethers with fellow members who live nearby, often held in local cafes. These meetings are opportunities to ask questions about timebanking and receive technical support and information, as well as to arrange new time trades in person instead of online. This approach distributes some of the administrative burden away from the timebank's organizational centre, and builds capacity amongst the membership by training new organizers.

Difficult management decisions are being made within a wider climate of government funding cuts to a number of community organizations and social services in New Zealand, and the pool of funding available overall is becoming more and more competitive. Other aspects of the broader context of these shifts in trading activity whether up or down, are also necessary to consider. At the beginning of my fieldwork, in 2011, I spoke informally with the founder of a South Island timebank that had briefly become established but folded soon after. When I asked him what had led to the failure of the timebank, he replied that it was not that the timebank had failed, rather that it had transformed into a community garden. In addition, many coordinators of timebanks that have stalled have devoted considerable time, energy, and expertise to national organizing and resource sharing amongst timebanks in New Zealand. Their work has made important contributions to the ongoing process of discovering where timebanks work in New Zealand, and under which specific and locally designed styles of organization and administration. Different understandings of success 
and failure within this wider context, and what those terms mean to the people involved, would be a necessary component of future research into timebanks that have folded within New Zealand.

\begin{tabular}{|c|c|c|c|c|c|}
\hline Timebank & Location & $\begin{array}{c}\text { Active } \\
\text { Members }\end{array}$ & $\begin{array}{c}\text { No. of } \\
\text { Exchanges }\end{array}$ & $\begin{array}{c}\text { Hours } \\
\text { Exchanged }\end{array}$ & $\begin{array}{l}\text { Last Recorded Trade } \\
\text { (as of } 26 \text { March 2016) }\end{array}$ \\
\hline Timebank 1 & North Island & 181 & 695 & 1,395 & 4 hours 42 min ago \\
\hline Timebank 2 & North Island & 530 & 4,980 & 13,860 & 8 hours 3 min ago \\
\hline Timebank 3 & South Island & 173 & 1,340 & 4,922 & 11 hours 22 min ago \\
\hline Timebank 4 & North Island & 168 & 910 & 1,829 & 11 hours 43 min ago \\
\hline Timebank 5 & South Island & 735 & 9,063 & 119,448 & 13 hours 19 min ago \\
\hline Timebank 6 & North Island & 204 & 2,502 & 6,786 & 14 hours 47 min ago \\
\hline Timebank 7 & North Island & 75 & 649 & 2,484 & 1 day 4 hours ago \\
\hline Timebank 8 & North Island & 211 & 1,445 & 3,510 & 1 day 17 hours ago \\
\hline Timebank 9 & South Island & 248 & 490 & 3,494 & 3 days 5 hours ago \\
\hline Timebank 10 & North Island & 96 & 192 & 710 & 3 days 11 hours ago \\
\hline Timebank 11 & North Island & 99 & 1,297 & 6,906 & 4 days 4 hours ago \\
\hline Timebank 12 & South Island & 83 & 414 & 4,115 & 1 week 5 hours ago \\
\hline Timebank 13 & North Island & 344 & 1,991 & 6,101 & 1 week 1 day ago \\
\hline Timebank 14 & North Island & 26 & 37 & 68 & 2 weeks 6 days ago \\
\hline Timebank 15 & South Island & 43 & 197 & 313 & 6 weeks 5 days ago \\
\hline Timebank 16 & North Island & 148 & 192 & 899 & 22 weeks 12 hours ago \\
\hline Timebank 17 & South Island & 72 & 259 & 990 & 32 weeks 4 days ago \\
\hline Timebank 18 & North Island & 161 & 190 & 486 & 43 weeks 2 days ago \\
\hline Timebank 19 & North Island & 91 & 174 & 496 & 46 weeks 5 days ago \\
\hline Timebank 20 & South Island & 57 & 129 & 288 & 1 year 9 weeks ago \\
\hline Timebank 21 & North Island & 31 & 535 & 1,643 & 1 year 17 weeks ago \\
\hline Timebank 22 & North Island & 41 & 188 & 277 & 1 year 25 weeks ago \\
\hline Timebank 23 & North Island & 48 & 188 & 712 & 1 year 47 weeks ago \\
\hline Timebank 24 & South Island & 90 & 423 & 1,199 & 2 years 15 weeks ago \\
\hline Timebank 25 & South Island & 69 & 217 & 1,436 & 3 years 3 weeks ago \\
\hline Timebank 26 & South Island & 30 & 116 & 438 & 3 years 19 weeks ago \\
\hline $\begin{array}{l}\text { Timebank } 27 \\
\text { (not hosted by } \\
\text { TimeBanks } \\
\text { USA) }\end{array}$ & South Island & no data & no data & no data & $\begin{array}{l}\text { Active Facebook page } \\
\text { and website accessed } \\
\text { on 26/03/2016. }\end{array}$ \\
\hline Total & $\begin{array}{l}\text { North Isl. (16) } \\
\text { South Isl. (11) }\end{array}$ & 4,054 & 28,813 & 184,805 & \\
\hline
\end{tabular}

Table 1: Membership and trading statistics of established New Zealand timebanks. Data source: http://community.timebanks.org (TimeBanks USA International List) 


\section{Conclusion}

New Zealand's North Island timebank participants frequently reported that they have achieved personal goals of meeting a wider range of new people, building new networks of friendship and solidarity, and have felt satisfaction in helping to facilitate this for fellow members of their communities. This was achieved through person-to-person exchanges of skills, expertise, and labor, and through social events many of which were organized in partnership with aligned community groups. In several sites around New Zealand, timebanks have also formed enduring relationships with larger organizations, such as the strong working partnership that has emerged in Lyttelton between the timebank and Civil Defense. As explained above, this partnership formed as a result of high quality disaster relief and support work carried out by timebank members and organizers, in response to the Canterbury earthquakes (Ozanne and Ozanne, 2016).

Regarding the potential to catalyze broader economic and political change, timebanks in New Zealand have had many successes over the past few years, while also dealing with similar structural challenges as those identified in other activist and degrowth projects, including lack of institutional support, volunteer burn out, and the struggle to maintain livelihoods that can accommodate unpaid activist work. On this point, Kallis and March (2015: 366-7) make an observation that resonates with the results of my research:

The intriguing idea behind degrowth is that we do not need to 'develop' to get enough, because we already have, and in a sense always had, enough. What we need is to struggle for the institutions that will allow us to live with enough.

Within the context of timebanking in New Zealand, this includes not only new structures such as timebanks themselves, but also a social environment of tolerance, support, and respect for community developers who are carrying out crucial work at local scales to bring degrowth and post growth initiatives to life. Local and national government, and the business community, can become the institutions that will allow us to live with enough by fighting the dissolution of the welfare state, abolishing zero hour contracts, controlling financial speculation in the housing market, introducing a living wage and a universal basic income, and taking measures to reduce the debt burden of tertiary graduates, homeowners, and others. This approach would help alleviate the pressure on citizens to accept "bullshit jobs" (Graeber, 2013) that they do not find meaningful or useful. In addition, the more creativity and time that is put into developing alternative currencies, the more public discussions can expand regarding the social and cultural production of money. These discussions, which are already underway but could be taken further, help people to re-evaluate both money and the economy as human inventions that can be undone, re-imagined, and re-designed following the changing pressures and new priorities of living within increasingly stressed ecological systems. Clearly this is no small task, when government and corporate for-profit interests are so strongly aligned.

Many participants described their work developing timebanks as challenging, experimental, and responsive to community needs and interests. They frequently revisited and redesigned their goals and strategies, following a process of discovery as their timebanks grew and evolved. At times this meant stepping back, taking breaks, and re-evaluating to decide whether to press on with developing their timebank, or to rename and redesign their projects as something more relevant to their local contexts. Again this reflects the work of Kallis and March (2015: 366) who explain that degrowth "imagines a future of process and conflict, not a blissful end state; it subverts the hegemonic desires on which capitalism rests; it brings the past into the present and into the production of the future; and it aspires to the production of egalitarian socionatures." A key strength that timebanking can contribute to the production of such egalitarian socionatures, is the opportunity to step into spaces of possibility, innovation and solidarity with neighbors and new acquaintances. Timebanks achieve this by combining practical and tangible changes in their local community, with changes in how people inter-relate with one another. These changes co-exist and interact with those produced by other initiatives, all contributing to larger processes of transition towards broader political, ecological, and economic change. Regardless of how long each of these transitional moments may last, in the form of particular local timebanks, they all contribute to members' and organizers' understanding of what works, what 
feels satisfying, and what does not, and how to design the next iteration of their projects using the results of these experiments.

\section{References}

Burke, B. and B. Shear. 2014. Introduction: engaged scholarship for non-capitalist political ecologies. Journal of Political Ecology 21: 127-144.

Cahn, E. 2004. No more throw-away people: the co-production imperative. Washington, D.C.: Essential Books.

Demaria, F., F. Schneider, F. Sekulove and J. Martinez-Alier. 2013. What is de-growth? From an activist slogan to a social movement. Environmental Values 22: 191-215.

Dittmer, K. 2012. Two challenges for creating democratically accountable local currencies to cope with unvoluntary degrowth: lessons from Argentina. Venice: 3rd International Conference on Degrowth, Ecological Sustainability and Social Equity.

Dittmer, K. 2013. Local currencies for purposive degrowth? A quality check of some proposals for changing money-as-usual. Journal of Cleaner Production 54: 3-13. Researchgate

Gardner, D. (Writer and Director) 2011. Growthbusters [Film] United States: GrowthBusters (Production company).

Generation Zero. 2011-2016. Retrieved February 05, 2016. www.generationzero.org/about

Graeber, D. 2013. On the phenomenon of bullshit jobs. Strike! Magazine. August 17.

Jackson, M. 1995. Helping ourselves: New Zealand's green dollar exchanges. ANZAC Fellowship Report. [Available at: http://tinyurl.com/Jackson-1995]

Kallis, G. and H. March. 2015. Imaginaries of hope: the utopianism of degrowth. Annals of the Association of American Geographers 105(2): 360-368. Academia

McGuirk, E. 2012. Studying time banking: exploring participatory action research in Aotearoa New Zealand. Sites: a Journal of Social Anthropology and Cultural Studies 9(2): 142-171.

North, P. 2007. Money and liberation: the micropolitics of alternative currency movements. Minneapolis: University of Minnesota Press.

North, P. 2010. Alternative currency networks as utopian practice. In Leonard, L. and J. Barry (eds.) Global ecological politics. Bingley, UK: Emerald. Pp 73-88.

Ozanne, L. and J.L. Ozanne. 2016. How alternative consumer markets can build community resiliency. European Journal of Marketing 50(3/4): 330-357.

Paulson, S. 2017. Degrowth: culture, power and change. Journal of Political Ecology 24: 425-448.

Williams, C. 1996. Local currencies and community development: an evaluation of green dollar exchanges in New Zealand. Community Development Journal 31(4): 319-329. Researchgate 